\title{
Shifting ocean carbonate chemistry during the Eocene-Oligocene climate transition: Implications for deep-ocean $\mathrm{Mg} / \mathrm{Ca}$ paleothermometry
}

\author{
V. L. Peck, ${ }^{1}$ J. Yu, ${ }^{2}$ S. Kender, ${ }^{3}$ and C. R. Riesselman ${ }^{4}$ \\ Received 7 December 2009; revised 23 August 2010; accepted 9 September 2010; published 4 December 2010.
}

[1] To date, no conclusive evidence has been identified for intermediate or deep water cooling associated with the $>1 \%$ benthic $\delta^{18} \mathrm{O}$ increase at the Eocene-Oligocene transition (EOT) when large permanent ice sheets first appeared on Antarctica. Interpretation of this isotopic shift as purely ice volume change necessitates bipolar glaciation in the early Oligocene approaching that of the Last Glacial Maximum. To test this hypothesis, it is necessary to have knowledge about deep water temperature, which previous studies have attempted to reconstruct using benthic foraminiferal $\mathrm{Mg} / \mathrm{Ca}$ ratios. However, it appears likely that contemporaneous changes in ocean carbonate chemistry compromised the $\mathrm{Mg} / \mathrm{Ca}$ temperature sensitivity of benthic foraminifera at deep sites. New geochemical proxy records from a relatively shallow core, ODP Site 1263 (estimated paleodepth of $2100 \mathrm{~m}$ on the Walvis Ridge), reveal that carbonate chemistry change across the EOT was not limited to deep sites but extended well above the lysocline, critically limiting our ability to obtain reliable estimates of deep-ocean cooling during that time. Benthic $\mathrm{Li} / \mathrm{Ca}$ measurements, used as a proxy for $\left[\mathrm{CO}_{3}^{2-}\right]$, suggest that $\left[\mathrm{CO}_{3}^{2-}\right]$ increased by $\sim 29 \mu \mathrm{mol} / \mathrm{kg}$ at Site 1263 across the EOT and likely impacted benthic foraminiferal $\mathrm{Mg} / \mathrm{Ca}$. A $\left[\mathrm{CO}_{3}^{2-}\right]-$ benthic $\mathrm{Mg} / \mathrm{Ca}$ relationship is most apparent during the early EOT when the overall increase in $\left[\mathrm{CO}_{3}^{2-}\right]$ is interrupted by an apparent dissolution event. Planktonic $\delta^{18} \mathrm{O}$ and $\mathrm{Mg} / \mathrm{Ca}$ records suggest no change in thermocline temperature and a $\delta^{18} \mathrm{O}_{\text {seawater }}$ increase of up to $0.6 \%$ at this site across the EOT, consistent with previous estimates and supporting the absence of extensive bipolar glaciation in the early Oligocene.

Citation: Peck, V. L., J. Yu, S. Kender, and C. R. Riesselman (2010), Shifting ocean carbonate chemistry during the EoceneOligocene climate transition: Implications for deep-ocean $\mathrm{Mg} / \mathrm{Ca}$ paleothermometry, Paleoceanography, 25, PA4219,

doi:10.1029/2009PA001906.

\section{Introduction}

[2] The $>1 \%$ increase in deep-sea benthic $\delta^{18} \mathrm{O}$ at the Eocene-Oligocene transition (EOT) represents the onset of a first permanent ice sheet on Antarctica [Zachos et al., 2001]. Climate modeling [DeConto and Pollard, 2003] shows that the ensuing $\delta^{18} \mathrm{O}$ shift likely reflects changes in both global ice volume and ambient bottom water temperature. Attempts to quantify the degree of deep-sea cooling across the EOT using benthic foraminiferal $\mathrm{Mg} / \mathrm{Ca}$ records suggested a slight warming of bottom waters [Lear et al., 2000; Billups and Schrag, 2003; Lear et al., 2004] which in conjunction with a benthic $\delta^{18} \mathrm{O}$ increase would imply a substantial bipolar glaciation on a scale comparable to the Last Glacial Maximum (LGM) [Lear et al., 2004; Coxall et al., 2005;

\footnotetext{
${ }^{1}$ British Antarctic Survey, Cambridge, UK.

${ }^{2}$ Lamont-Doherty Earth Observatory of Columbia University, Palisades, New York, USA.

${ }^{3}$ British Geological Survey, Nottingham, UK.

${ }^{4}$ Department of Geological and Environmental Sciences, Stanford University, Stanford, California, USA.

Copyright 2010 by the American Geophysical Union. 0883-8305/10/2009PA001906
}

Eldrett et al., 2007]. However, sequence stratigraphy estimates a maximum sea level fall of $\sim 70 \mathrm{~m}$, limiting the ice volume component of the benthic $\delta^{18} \mathrm{O}$ increase to $\sim 0.7 \%$ [Pekar et al., 2002; Miller et al., 2008]. One possible explanation is that contemporaneous changes in carbonate chemistry compromised $\mathrm{Mg} / \mathrm{Ca}$ temperature sensitivity, such as observed today in settings where ambient bottom water carbonate ion concentrations $\left(\left[\mathrm{CO}_{3}^{2-}\right]\right)$ change measurably on glacial-interglacial timescales [Elderfield et al., 2006; Yu and Elderfield, 2008]. A deepening of the carbonate compensation depth (CCD) across the EOT observed in all deep-ocean basins [Van Andel, 1975] is diagnostic of such changes in carbonate chemistry.

[3] Benthic $\mathrm{Mg} / \mathrm{Ca}$ records across the EOT to date come from sites that in the latest Eocene were at a similar depth as the CCD (ODP Site 1218 [Lear et al., 2004]), or that were positioned within the lysocline where the first increases in $\mathrm{CaCO}_{3}$ dissolution occur (DSSP Site 552 [Lear et al., 2000]). Lear et al. [2004] hypothesize that increasing benthic $\mathrm{Mg} / \mathrm{Ca}$ values across the EOT reflect a dramatic rise in $\left[\mathrm{CO}_{3}^{2-}\right]$ at these deep sites, which is supported by increasing $\mathrm{Li} / \mathrm{Ca}$ ratios [Lear and Rosenthal, 2006; Lear et al., 2010] that serve as a proxy for $\left[\mathrm{CO}_{3}^{2-}\right]$ as opposed to a secondary temperature influence [Marriott et al., 2004]. Because these 


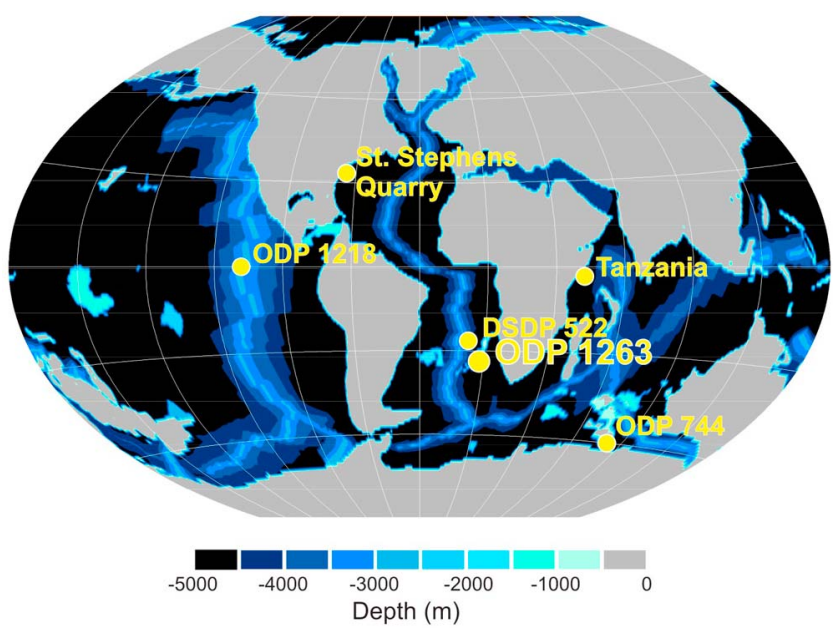

Figure 1. Paleolocations of ODP Site 1263 and other sites referred to in the discussion, plotted on a map of EoceneOligocene bathymetry and geography [Müller et al., 2008].

cores are from a depth range over which deep water $\left[\mathrm{CO}_{3}^{2-}\right]$ changes are likely to have had the greatest influence on foraminiferal $\mathrm{Mg} / \mathrm{Ca}$ temperature sensitivity, our ability to constrain deep water temperature changes remains limited. We present a benthic $\mathrm{Mg} / \mathrm{Ca}$ record from Site 1263, at Walvis Ridge, SE Atlantic, which was located at $\sim 2100 \mathrm{~m}$ water depth in the latest Eocene and positioned $\sim 1 \mathrm{~km}$ above the regional lysocline [Zachos et al., 2004] prior to the abrupt lysocline/CCD deepening at the EOT. Complementary benthic stable isotope $\left(\delta^{18} \mathrm{O}\right)$ [Riesselman et al., 2007] and elemental ratio $(\mathrm{Sr} / \mathrm{Ca}, \mathrm{Li} / \mathrm{Ca})$ records are used to constrain the carbonate chemistry of ambient bottom waters at Site 1263 and to test for the reliability of the benthic $\mathrm{Mg} / \mathrm{Ca}$ record as an indicator of deep water temperature [Lear and Rosenthal, 2006; Lear et al., 2010] at shallow water depths across the EOT.

\section{Material and Methods}

[4] Site $1263\left(28^{\circ} 31.98^{\prime} \mathrm{S}, 2^{\circ} 46.77^{\prime} \mathrm{E}\right)$ was cored during ODP Leg 208 on Walvis Ridge in the SE Atlantic (Figure 1). The site is at a modern water depth of $2717 \mathrm{~m}$, and represents the shallow drill site of the Leg 208 depth transect across Walvis Ridge. The age model for Site 1263 is based on sixtytwo biostratigraphic and six magnetostratigraphic datums [Zachos et al., 2004]. The seven age/depth points encompassing the latest Eocene and earliest Oligocene stratigraphy that was developed by the Leg 208 shipboard party represent calcareous nannofossil and planktonic foraminifer datums [Bukry, 1973, 1975; Okada and Bukry, 1980; Berggren et al., 1995; Zachos et al., 2004]; the C13n magnetochron is partially resolved [Cande and Kent, 1995]. We apply a secondorder polynomial regression to these seven age/depth points to generate the age model used here [Riesselman et al., 2007].

[5] A benthic $\delta^{18} \mathrm{O}$ record with $\sim 6 \mathrm{kyr}$ temporal resolution has been produced for Site 1263 using the infaunal foraminifera Oridorsalis umbonatus [Riesselman et al., 2007]. The record displays a $1.1 \%$ increase in benthic $\delta^{18} \mathrm{O}$ across the EOT (Figure 2) and the structure of the $\delta^{18} \mathrm{O}$ record suggests the sediment sequence representing the EOT is intact and not disturbed by downslope transportation or reworking. We note that the age model for Site 1263 is not as robust as the orbitally tuned age model of ODP Site 1218 [Coxall et al., 2005]; however, sedimentation rates of $\sim 1.5 \mathrm{~cm} / \mathrm{kyr}$ provide the highest-resolution Atlantic record for the EOT time interval [Zachos et al., 2004].

[6] Optical lightness $\left(\mathrm{L}^{*}\right)$ and magnetic susceptibility measurements of the suite of Leg 208 cores indicate the regional lysocline was positioned between Sites 1266 (3806 m water depth) and 1267 (4356 m water depth) in the latest Eocene [Zachos et al., 2004]. Site 1263 was therefore positioned at least $1 \mathrm{~km}$ above the lysocline prior to CCD deepening. At Walvis Ridge the lysocline/CCD is determined to have deepened in excess of $1 \mathrm{~km}$ across the EOT [Zachos et al., 2004], similar to other estimates from the Atlantic Ocean and intermediate between the Indian and Pacific Oceans, in which the CCD deepened by up to $700 \mathrm{~m}$ and $\sim 1200 \mathrm{~m}$, respectively [Coxall and Pearson, 2007, and references therein]. $\% \mathrm{CaCO}_{3}$ of core material collected from Site 1263 ranges from 88 to $96 \%$ (averaging 93\%) through the interval 33.9-32.7 Ma [Riesselman et al., 2007].

[7] For elemental ratio analysis, additional $O$. umbonatus specimens were picked from the $150-250 \mu \mathrm{m}$ size fraction. For planktonic $\mathrm{Mg} / \mathrm{Ca}$ and stable isotope analyses, surface dwelling Turborotalia ampliapertura and thermocline dwelling Subbottina utilizindex were picked from the 250-300 $\mu \mathrm{m}$ size fraction. Between 15 and 30 specimens of each species were collected from each sample. The specimens were placed between two glass plates and carefully cracked open. For planktonic samples containing more than 20 specimens the crushed tests were homogenized and aliquots were taken for elemental ratio and stable isotope analysis. Stable isotopes were measured on a PRISM mass spectrometer at Cambridge University with an analytical precision of $\sim 0.08 \%$ for $\delta^{18} \mathrm{O}$ and $0.06 \%$ for $\delta^{13} \mathrm{C}$.

[8] Samples were cleaned for elemental ratio analysis following cleaning protocols outlined by Barker et al. [2003], with no reductive step and five weak acid leaches [Yu et al., 2007]. Complementary $\mathrm{Sr} / \mathrm{Ca}$ and $\mathrm{Li} / \mathrm{Ca}$ measurements were carried out on benthic samples that were large enough to provide $\sim 300 \mu 1$ of $100 \mathrm{ppm} \mathrm{Ca}$ solution. These measurements were made on a quadrupole ICP-MS according to the method described by $Y u$ et al. [2005] and were intended to serve as additional indicators of possible change in ambient bottom water $\left[\mathrm{CO}_{3}^{2-}\right]$. Samples containing fewer specimens were run at $60 \mathrm{ppm}$ Ca on Varian Vista ICP-AES for $\mathrm{Mg} / \mathrm{Ca}$ measurements only. Replicate measurements of standards indicate reproducibility of $\pm 0.03 \mathrm{mmol} / \mathrm{mol}$, $\pm 0.01 \mathrm{mmol} / \mathrm{mol}$, and $\pm 0.32 \mu \mathrm{mol} / \mathrm{mol}$ for $\mathrm{Mg} / \mathrm{Ca}, \mathrm{Sr} / \mathrm{Ca}$, and $\mathrm{Li} / \mathrm{Ca}$, respectively.

\section{Results}

\section{1. $\delta^{18} \mathrm{O}$ and $\% \mathrm{CaCO}_{3}$}

[9] Across the EOT, published benthic $\delta^{18} \mathrm{O}$ records from Site 1263 display an increase of $\sim 1.1 \%$, from $\sim 1.5 \%$ in the latest Eocene to $2.6 \%$ in the earliest Oligocene (Figure 2c) [Riesselman et al., 2007]. Although not as clearly defined as 


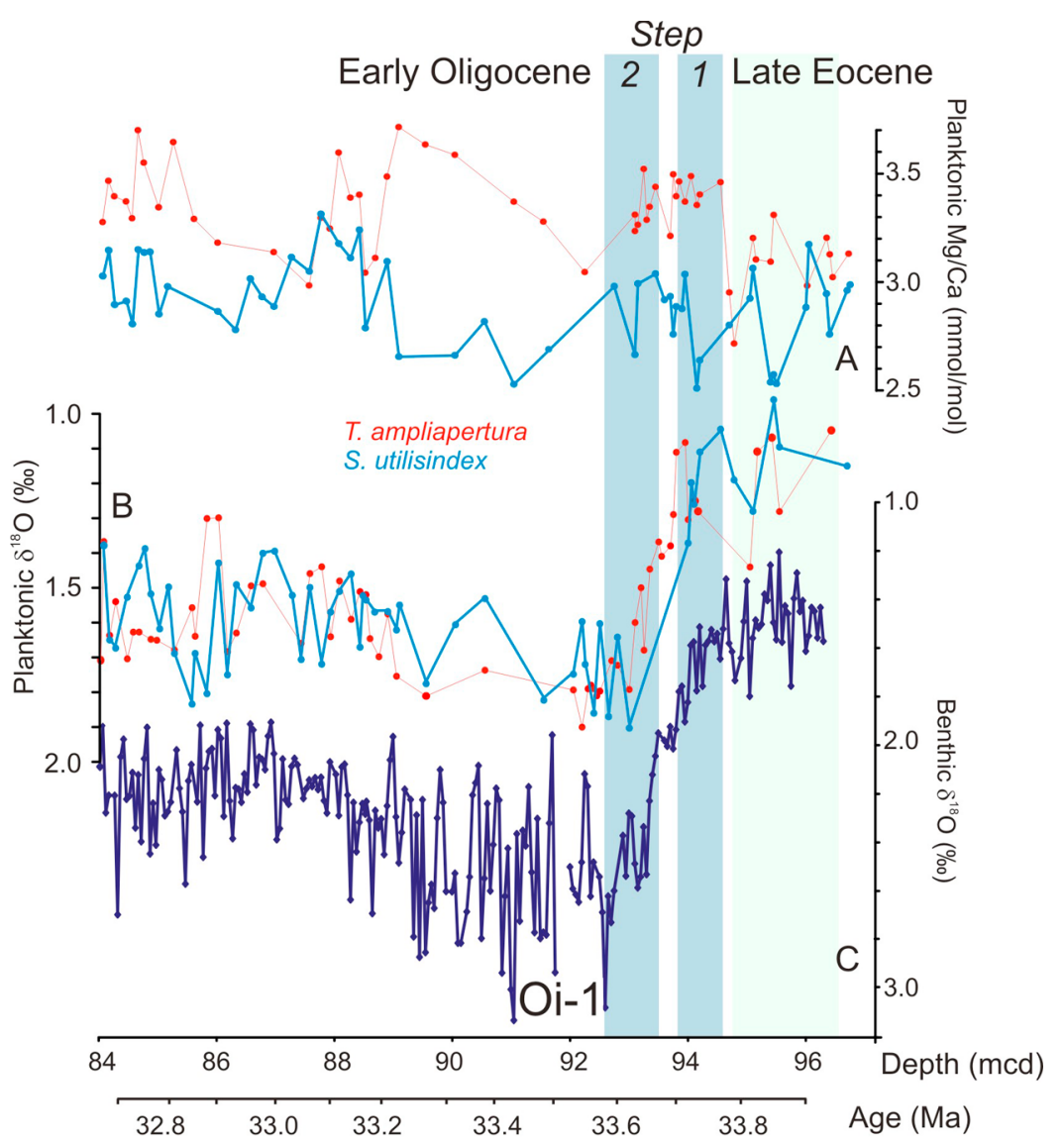

Figure 2. Planktonic foraminifera $\delta^{18} \mathrm{O}$ and $\mathrm{Mg} / \mathrm{Ca}$ records from ODP Site 1263. (a) Planktonic $\mathrm{Mg} / \mathrm{Ca}$, (b) planktonic $\delta^{18} \mathrm{O}$ from surface-dwelling T. ampliapertura (red) and thermocline-dwelling S. utilizindex (blue), and (c) benthic foraminifera $\delta^{18} \mathrm{O}$ (O. umbonatus) [Riesselman et al., 2007]. Vertical bars indicate the latest Eocene and Steps 1 and 2 of the EOT.

at Site 1218 [Coxall et al., 2005], Steps 1 and 2 of the $\delta^{18} \mathrm{O}$ increase can be identified at Site 1263. Step 1 represents a $0.5 \%$ increase over $\sim 80 \mathrm{kyr}$, while Step 2 represents a $0.6 \%$ increase over $\sim 90 \mathrm{kyr}$ [Riesselman et al., 2007]. The $\delta^{18} \mathrm{O}$ records of $T$. ampliapertura and $S$. utilizindex display a smaller shift, increasing by $\sim 0.6 \%$, from $\sim 1.2 \%$ o to $\sim 1.8 \%$ o during the EOT (Figure $2 \mathrm{~b}$ ). Average $\mathrm{oCaCO}_{3}$ values before and after the transition are similar, at $92 \%(\mathrm{n}=46)$ and $93 \%(n=198)$, respectively (Figure 3a). At the onset of the $\delta^{18} \mathrm{O}$ increase, $\% \mathrm{CaCO}_{3}$ values fall to a transient minimum of $88 \%$ (hereafter referred to as the dissolution event) early in Step $1 . \% \mathrm{CaCO}_{3}$ values progressively increase during the second half of Step 1 and reach latest Eocene values at the end of Step 2 (Figure 3a).

\subsection{Elemental Ratio Records}

[10] At the onset of Step 1 , the average $\mathrm{Mg} / \mathrm{Ca}$ ratio of surface-dwelling $T$. ampliapertura increases from $\sim 3.1 \mathrm{mmol} / \mathrm{mol}$ in the latest Eocene to $\sim 3.4 \mathrm{mmol} / \mathrm{mol}$ (Figure 2a) and these elevated values are maintained across Step 1. S. utilizindex $\mathrm{Mg} / \mathrm{Ca}$ fluctuates between 2.5 to $3.1 \mathrm{mmol} / \mathrm{mol}$ across the EOT, but shows no change in average values across the EOT. In the early Oligocene, $\mathrm{Mg} / \mathrm{Ca}$ records of both species fluctuate but display an overall increase of $\sim 0.2 \mathrm{mmol} / \mathrm{mol}$ relative to the latest Eocene by the end of the studied interval.

[11] Benthic $\mathrm{Mg} / \mathrm{Ca}$ increases across the EOT and into the early Oligocene, from an average value of $2.4 \mathrm{mmol} / \mathrm{mol}$ before the benthic $\delta^{18} \mathrm{O}$ increase, to values approaching $2.8 \mathrm{mmol} / \mathrm{mol}$ after $33.0 \mathrm{Ma}$ (Figure 3c). Lowest benthic $\mathrm{Mg} / \mathrm{Ca}$ values precede the benthic $\delta^{18} \mathrm{O}$ increase in the Latest Eocene, coincident with a $\% \mathrm{CaCO}_{3}$ maximum. As $\% \mathrm{CaCO}_{3}$ decreases in Step 1, Mg/Ca increases and then directly mimics the trend of the $\% \mathrm{CaCO}_{3}$ record through Steps 1 and 2 with $\mathrm{Mg} / \mathrm{Ca}$ values increasing with rising $\% \mathrm{CaCO}_{3}$ (Figure 4).

[12] Benthic $\mathrm{Sr} / \mathrm{Ca}$ (Figure 3d) varies within a range from 0.83 to $0.89 \mathrm{mmol} / \mathrm{mol}$. In the latest Eocene, values average $0.86 \mathrm{mmol} / \mathrm{mol}$, decreasing to $\sim 0.84 \mathrm{mmol} / \mathrm{mol}$ across the EOT and then increase toward the end of the studied interval. Several $\mathrm{Sr} / \mathrm{Ca}$ excursions during the latest Eocene and Step 1 are antiphased with $\mathrm{Mg} / \mathrm{Ca}$.

[13] The first-order trends in the lower-resolution $\mathrm{Li} / \mathrm{Ca}$ record (Figure 3b) show some similarity with those of the higher-resolution $\% \mathrm{CaCO}_{3}$ record. $\mathrm{Li} / \mathrm{Ca}$ values increase from $\sim 14 \mathrm{mmol} / \mathrm{mol}$ to $\sim 16 \mathrm{mmol} / \mathrm{mol}$ prior to Step 1 , coincident with $\% \mathrm{CaCO}_{3}$ rise to a brief maximum of 96\%. $\mathrm{Li} / \mathrm{Ca}$ ratios and $\% \mathrm{CaCO} 3$ decrease within Step 1, and from Step 2 onward $\mathrm{Li} / \mathrm{Ca}$ stabilizes at $\sim 15 \mathrm{mmol} / \mathrm{mol}$, 


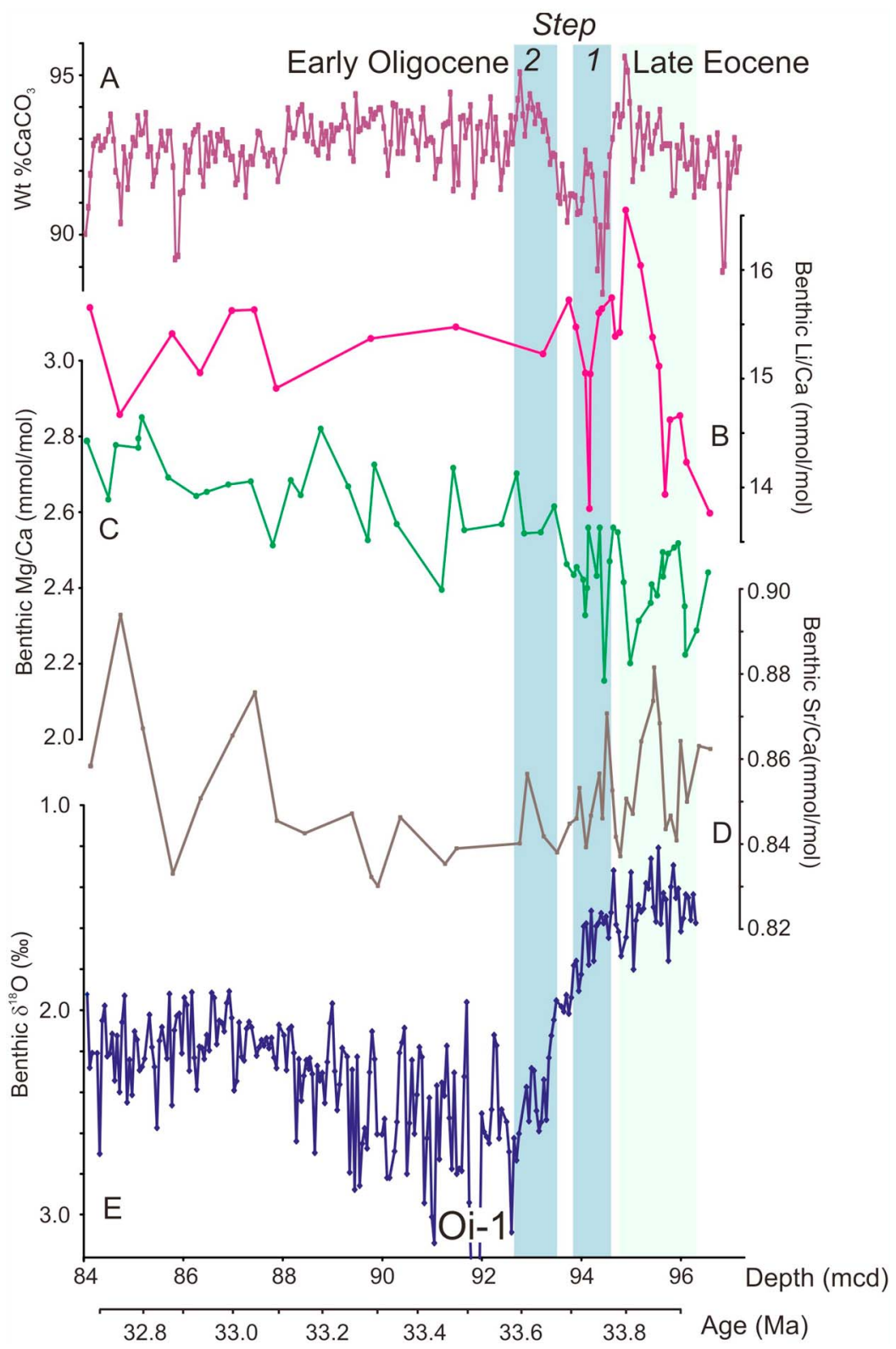

Figure 3. Records of $\% \mathrm{CaCO}_{3}$, benthic foraminiferal $\delta^{18} \mathrm{O}$ and elemental ratios from ODP Site 1263 . (a) Weight $\% \mathrm{CaCO}_{3}$ [Riesselman et al., 2007], (b) $\mathrm{Li} / \mathrm{Ca}$, (c) $\mathrm{Mg} / \mathrm{Ca}$, (d) $\mathrm{Sr} / \mathrm{Ca}$, and (e) $\delta^{18} \mathrm{O}[$ Riesselman et al., 2007]. All from O. umbonatus. Vertical bars indicate the latest Eocene and Steps 1 and 2 of the EOT.

$1 \mathrm{mmol} / \mathrm{mol}$ higher than values in the latest Eocene. The trend in $\mathrm{Li} / \mathrm{Ca}$ indicates the influence of $\left[\mathrm{CO}_{3}^{2-}\right][$ Marriott et al., $2004]$ in association with a deepening CCD across the EOT [Van Andel, 1975; Lear and Rosenthal, 2006]. The apparent increase in $\left[\mathrm{CO}_{3}^{2-}\right]$ at this site has potential implications for carbonate preservation and benthic foraminiferal $\mathrm{Mg} / \mathrm{Ca}$, as will be discussed below.

\section{Discussion}

\subsection{Planktonic Records and $\delta w$}

[14] Before considering any implications of these data we must first assess the preservation of the planktonic forami- nifera. In specimens selected from the high $\% \mathrm{CaCO}_{3}$ interval at $94.89 \mathrm{mcd}$ and the low $\% \mathrm{CaCO}_{3}$ dissolution event at $94.44 \mathrm{mcd}$, scanning electron microscopy shows extensive recrystallization of the tests of both planktonic foraminiferal species (Figure 5). In addition, it was noted that specimens within the dissolution event were more susceptible to shattering (i.e., more fragile) during the cleaning process. Nonpristine or "frosty" planktonic foraminifera from deep-sea sites have been found to exhibit consistently heavier $\delta^{18} \mathrm{O}$ values than pristine, or "glassy," foraminifera from similar latitude sites, due to the recrystallization of calcite in cold seafloor conditions [Pearson 


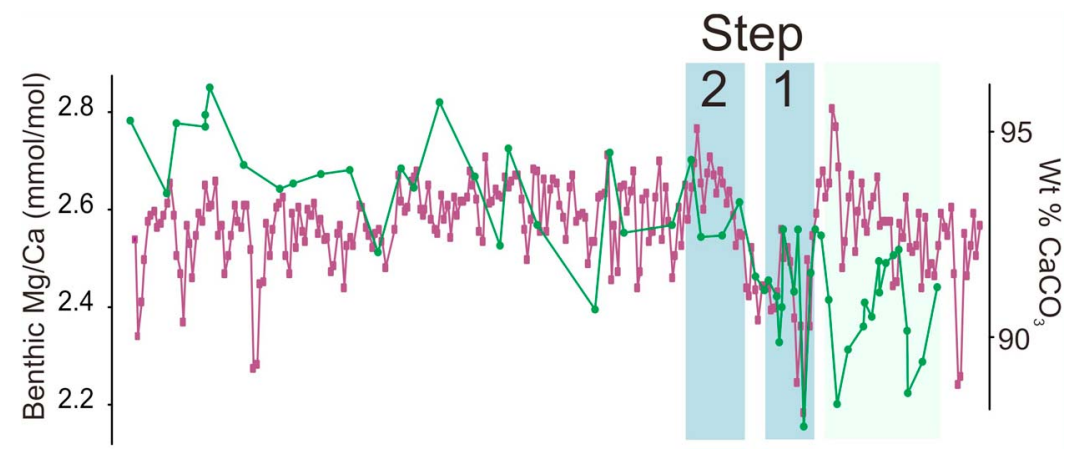

Figure 4. Expanded view of benthic $\mathrm{Mg} / \mathrm{Ca}$ and weight $\% \mathrm{CaCO}_{3}$ records showing close correlation across Steps 1 and 2. Vertical bars as in Figures 2 and 3.

et al., 2001; Sexton et al., 2006]. Had there been bottom water cooling at this site across the EOT, the degree of diagenetic overprinting on the planktonic shells may have increased, biasing the planktonic $\delta^{18} \mathrm{O}$ toward heavier values such that the similarity of the planktonic and benthic $\delta^{18} \mathrm{O}$ records at Site 1263 may in part be attributed to a diagenetic component [Pearson et al., 2001]. That is, the planktonic $\delta^{18} \mathrm{O}$ increase may be an artifact stemming from post depositional alteration under colder ambient bottom waters during the EOT in addition to a global change in seawater $\delta^{18} \mathrm{O}(\delta \mathrm{w})$ and/or surface water cooling. As we are unable to quantify the degree of diagenetic overprinting on the planktonic $\delta^{18} \mathrm{O}$, we consider the $0.6 \%$ increase to represent the maximum shift caused by SST cooling and $\delta \mathrm{w}$ increase.

[15] The effect of diagenetic alteration on planktonic foraminiferal $\mathrm{Mg} / \mathrm{Ca}$ is less well understood, but it has been observed that $\mathrm{Mg} / \mathrm{Ca}$ in frosty specimens is only marginally higher than in glassy specimens of the same species [Sexton et al., 2006]. The $\mathrm{Mg} / \mathrm{Ca}$ values of surface-dwelling $T$. ampliapertura are consistently higher than subsurfacedwelling S. utilizindex which would be consistent with their depth habitats [Pearson et al., 2006], assuming similar $\mathrm{Mg}^{2+}$ incorporation for both species. T. ampliapertura displays an apparent warming at the onset of Step 1 as average $\mathrm{Mg} / \mathrm{Ca}$ values increase from 3.1 to $3.4 \mathrm{mmol} / \mathrm{mol}$. Assuming a $\sim 1{ }^{\circ} \mathrm{C} / 9 \%$ sensitivity of $\mathrm{Mg} / \mathrm{Ca}$ [e.g., Anand et al., 2003], this change would represent $\mathrm{a} \sim 1^{\circ} \mathrm{C}$ warming, within the range of the $\pm 1.2^{\circ} \mathrm{C}$ calibration uncertainty [Anand et al., 2003]. However, as this increase in T. ampliapertura $\mathrm{Mg} / \mathrm{Ca}$ is coincident with an increase in benthic $\mathrm{Mg} / \mathrm{Ca}$ we consider the possibility of postdepositional alteration of planktonic $\mathrm{Mg} / \mathrm{Ca}$ ratios under changing seafloor $\left[\mathrm{CO}_{3}^{2-}\right]$. Further evidence in support of postdepositional alteration is the similarity of the planktonic $\delta^{18} \mathrm{O}$ records, which unlike the $\mathrm{Mg} / \mathrm{Ca}$ records do not display a temperature-related interspecies $\delta^{18} \mathrm{O}$ offset. We propose that the thinner test of the surface-dwelling $T$. ampliapertura may have been more susceptible to diagenetic alteration than the more robust test of subsurface-dwelling $S$. utilizindex as may be interpreted by T. ampliapertura $-\mathrm{Mg} / \mathrm{Ca}$ covariability with benthic $\mathrm{Mg} / \mathrm{Ca}$. We therefore consider that of the two planktonic $\mathrm{Mg} / \mathrm{Ca}$ records it is possible that a primary temperature signal may be preserved in the $S$. utilizindex $\mathrm{Mg} / \mathrm{Ca}$ record and pro- pose that no significant change in thermocline temperature occurred across the EOT at this site. The apparent stability of upper ocean temperatures inferred from the planktonic $\mathrm{Mg} / \mathrm{Ca}$ is consistent with nannofossil assemblage data from this same site. The relative abundances of warm and cold species do not change significantly across the benthic $\delta^{18} \mathrm{O}$ increase, suggesting negligible change in SST (F. Tori, personal communication, 2008) and similarly, SSTs from the tropical Atlantic (ODP sites 925 and 929), reconstructed using $\mathrm{U}^{\mathrm{K}^{\prime}} 37$, also show little temperature change across the EOT [Liu et al., 2009]. At higher latitudes, $\mathrm{U}^{\mathrm{K}^{\prime}} 37$ and $\mathrm{TEX}_{86}$ records indicate cooling synchronous with the benthic $\delta^{18} \mathrm{O}$ increase averaging $4.8^{\circ} \mathrm{C}$ [Liu et al., 2009]. While independent SST estimators are not available for Site 1263 , the planktonic $\mathrm{Mg} / \mathrm{Ca}$ and nannofossil assemblage records at this midlatitude site suggest a stronger affiliation with tropical SST stability than with high-latitude SST cooling across the EOT.

[16] Assuming S. utilizindex $\mathrm{Mg} / \mathrm{Ca}$ is predominantly documenting temperature, and that there was negligible change in thermocline temperature at this locality across the EOT, the planktonic $\delta^{18} \mathrm{O}$ increase of $0.6 \%$ can be considered to represent changes in $\delta \mathrm{w}$ only. Taken at face value, this maximum value for $\delta \mathrm{w}$ change is in agreement with a similar $\delta \mathrm{w}$ increase across the EOT observed in exceptionally preserved planktonic foraminifera from Tanzania [Lear et al., 2008], and also with an estimated sea level fall of about $60 \mathrm{~m}$ [DeConto and Pollard, 2003; Miller et al., 2008]. In the case of a $0.6 \%$ change in $\delta \mathrm{w}$, cooling of deep or intermediate waters in the range of $2^{\circ} \mathrm{C}$ is needed to account for the remaining $\sim 0.5 \%$ increase in benthic $\delta^{18} \mathrm{O}$ at Site 1263.

\section{2. $\mathrm{CCD}$ Deepening and $\left[\mathrm{CO}_{3}^{2-}\right]$ Increase at ODP Site 1263 With Implications for $\mathrm{Mg} / \mathrm{Ca}$}

[17] A dominant feature of the EOT is a deepening of the CCD by $\sim 1 \mathrm{~km}$, which has been attributed to a global shift in carbonate deposition from the shelf regions to the open ocean in response to significant sea level fall as ice accumulated on Antarctica [Merico et al., 2008]. Site 1263 was situated well above the lysocline in the latest Eocene, and we observe no significant increase in average $\% \mathrm{CaCO}_{3}$ values from the Eocene to Oligocene, although we acknowledge that $\mathrm{CaCO}_{3}$ accumulation rates would provide a 

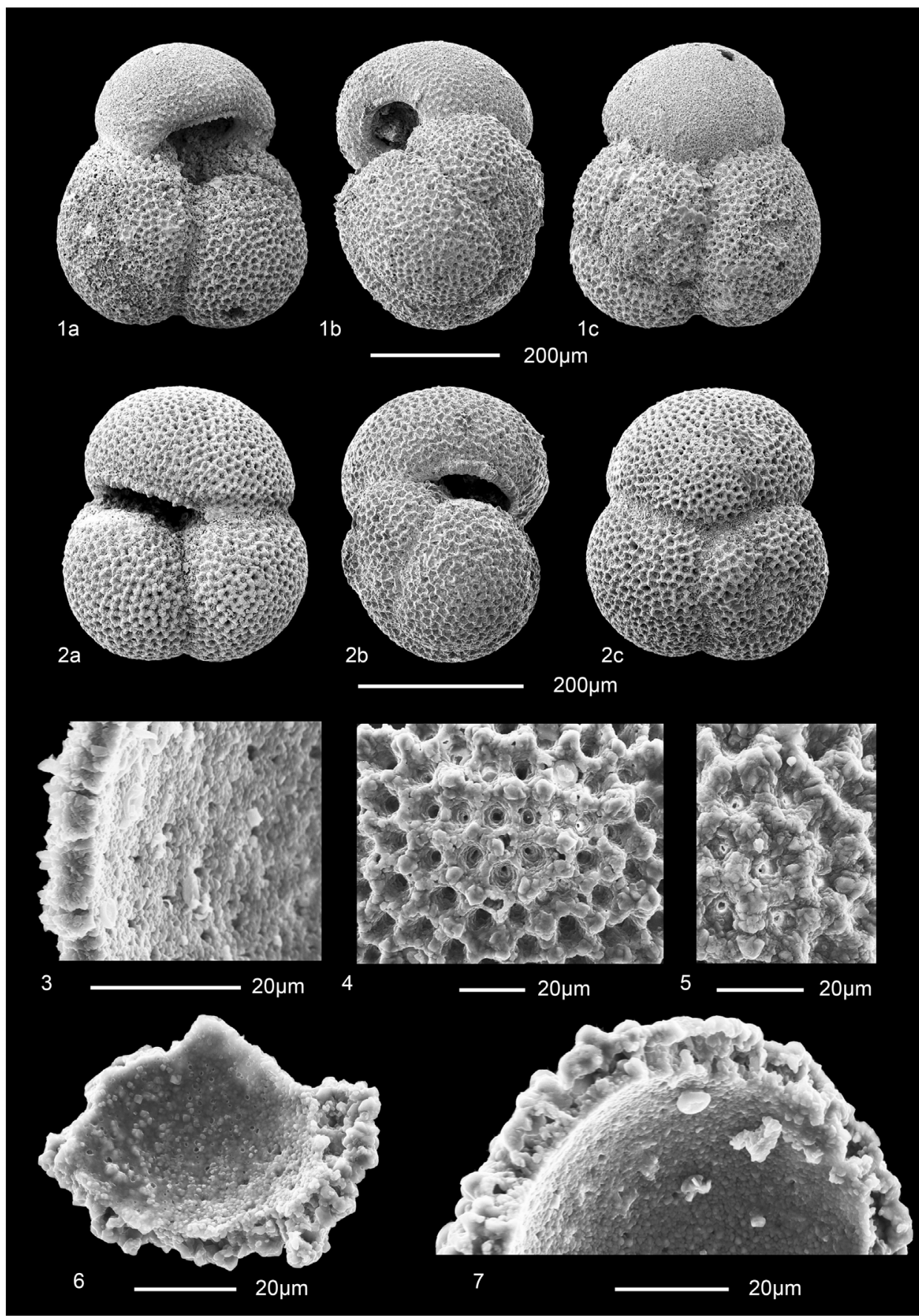

Figure 5. SEM images from planktonic foraminifera specimens from both a high $\% \mathrm{CaCO}_{3}$ interval (94.89 mcd) and the dissolution interval (94.44 mcd). Images 1a, 1b, and 1c, Turborotalia ampliapertura; images 2a, 2b, and 2c, Subbotina utilizindex; image 3, surface texture of T. ampliapertura from high $\% \mathrm{CaCO}_{3}$ interval; image 4 , surface texture of T. ampliapertura from dissolution interval; image 5 , surface texture of $S$. utilizindex from dissolution interval; image 6, wall texture of S. utilizindex from high $\% \mathrm{CaCO}_{3}$ interval; image 7, wall texture of $S$. utilizindex from dissolution interval.

more meaningful measure of changes in deposition and preservation. However, the transient decrease in $\% \mathrm{CaCO}_{3}$ at Step 1 (Figure 3a), a feature common to several sites including the Southern and Pacific Oceans (Figure 6), suggests that the overall increase in $\left[\mathrm{CO}_{3}^{2-}\right]$ across the EOT included an abrupt decrease in carbonate ion saturation state, or dissolution event, coincident with the onset of the benthic $\delta^{18} \mathrm{O}$ increase. At Site 1263, $\mathrm{Li} / \mathrm{Ca}$ values also fall in Step 1, but remain significantly higher than the latest Eocene average, suggesting that $\left[\mathrm{CO}_{3}^{2-}\right]$ had increased and/or 


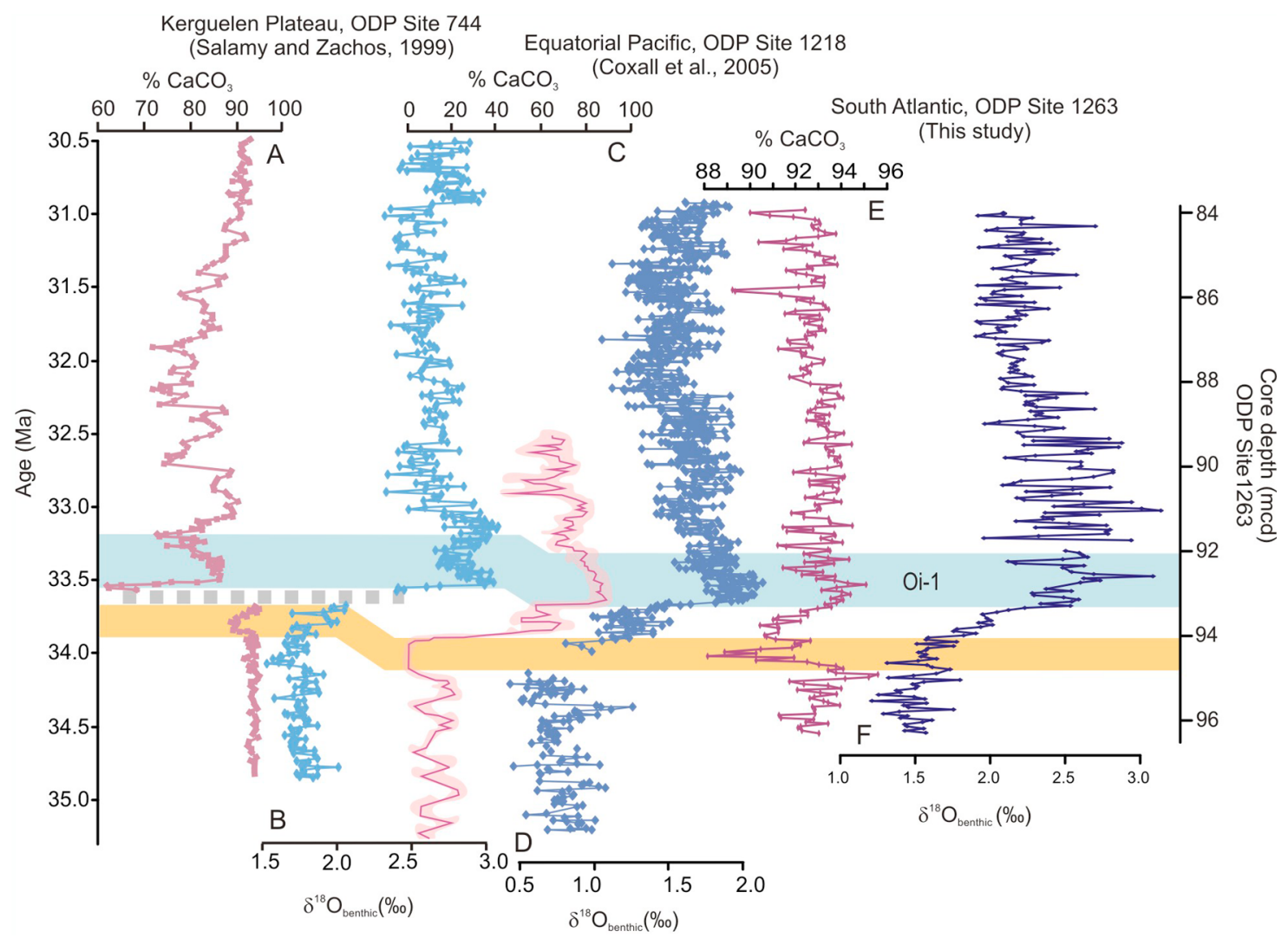

Figure 6. Evidence for dissolution horizon at the onset of the EOT in the South Atlantic, Southern, and Pacific oceans. (a) $\% \mathrm{CaCO}_{3}$ and (b) benthic $\delta^{18} \mathrm{O}$ from Site 744 [Salamy and Zachos, 1999]. Dashed gray line indicates coring disturbance. (c) $\% \mathrm{CaCO}_{3}$ and (d) benthic $\delta^{18} \mathrm{O}$ from Site 1218 [Coxall et al., 2005]. (e) $\% \mathrm{CaCO}_{3}$ and (f) benthic $\delta^{18} \mathrm{O}$ from Site 1263 [Riesselman et al., 2007]. Data from Sites 744 and 1218 are plotted on their published age models, while data from Site 1263 are plotted against depth. The blue horizontal bar indicates Oi-1, highlighting the correlation of the benthic $\delta^{18} \mathrm{O}$ maximum at each site. The orange horizontal bar locates the proposed dissolution horizon suggested at all three sites by minima in $\% \mathrm{CaCO}_{3}$. At Site 1218 a complete absence of carbonate accounts for the benthic $\delta^{18} \mathrm{O}$ data gap at this horizon.

bottom water temperatures had dropped relative to the latest Eocene. Higher $\Delta\left[\mathrm{CO}_{3}^{2-}\right]$ relative to latest Eocene conditions may account for benthic $\mathrm{Mg} / \mathrm{Ca}$ remaining above latest Eocene values even if bottom water temperatures did fall in Step 1. Furthermore, $\mathrm{Mg} / \mathrm{Ca}$ tracks $\% \mathrm{CaCO}_{3}$ in fine detail during the transient $\% \mathrm{CaCO}_{3}$ minimum (Figure 4 ) which is suggestive of a mechanistic linking between the two records through varying $\left[\mathrm{CO}_{3}^{2-}\right]$ in ambient bottom waters. This relationship is clearly different to the latest Eocene, prior to the benthic $\delta^{18} \mathrm{O}$ increase, when $\mathrm{Mg} / \mathrm{Ca}$ displays a negative relationship with both $\% \mathrm{CaCO}_{3}$ and $\mathrm{Li} / \mathrm{Ca}$. The sensitivity of $O$. umbonatus $\mathrm{Mg} / \mathrm{Ca}$ to changes in $\Delta\left[\mathrm{CO}_{3}^{2-}\right]$ has not yet been determined, but based on our data profiles we hypothesize that changes in $\left[\mathrm{CO}_{3}^{2-}\right]$ across the EOT have had a prominent influence on $\mathrm{Mg} / \mathrm{Ca}$.

[18] Site 1218 in the Equatorial Pacific was close to the $\mathrm{CCD}$ in the latest Eocene and $\% \mathrm{CaCO}_{3}$ increased from $\sim 10 \%$ to $>80 \%$ across the EOT (Figure 6) [Coxall et al., $2005]$ thus reflecting a substantial increase in ambient bottom water $\left[\mathrm{CO}_{3}^{2-}\right]$. Lear and Rosenthal [2006] record a $17 \%$ increase in $\mathrm{Li} / \mathrm{Ca}$ across the EOT at Site 1218 , occurring mostly within Step 1. A change of this magnitude would represent an approximately $37 \mu \mathrm{mol} / \mathrm{kg}$ increase in $\left[\mathrm{CO}_{3}^{2-}\right]$ at this site as the CCD deepened, although some of the $\mathrm{Li} / \mathrm{Ca}$ increase plausibly reflects deep water cooling [Marriott et al., 2004]. Applying the $\mathrm{Li} / \mathrm{Ca}-\Delta\left[\mathrm{CO}_{3}^{2-}\right]$ calibration of Lear and Rosenthal [2006] to Site 1263 suggests the $\sim 8 \%$ increase of $\mathrm{Li} / \mathrm{Ca}$ ratios was equivalent to a $\sim 29 \mu \mathrm{mol} / \mathrm{kg}$ $\left[\mathrm{CO}_{3}^{2-}\right]$ increase across the EOT, with the absolute $\left[\mathrm{CO}_{3}^{2-}\right]$ concentrations about $48 \mu \mathrm{mol} / \mathrm{kg}$ higher at Site 1263 than at the deep Pacific Site 1218.

[19] Recent studies have also demonstrated an inverse relationship between bottom water $\left[\mathrm{CO}_{3}^{2-}\right]$ and benthic foraminifera $\mathrm{Sr} / \mathrm{Ca}$; for example, Rathmann and Kuhnert [2008] found that a $0.05 \mathrm{mmol} / \mathrm{mol}$ decrease in $\mathrm{Sr} / \mathrm{Ca}$ corresponded to a $10 \mu \mathrm{mol} / \mathrm{kg}$ increase in $\left[\mathrm{CO}_{3}^{2-}\right]$ in a depth transect off Namibia. At Site 1263 we observe a $\mathrm{Sr} / \mathrm{Ca}$ decrease of $\sim 0.02 \mathrm{mmol} / \mathrm{mol}$ which is small compared to an expected decrease of $0.15 \mathrm{mmol} / \mathrm{mol}$ if one uses the $\mathrm{Sr} / \mathrm{Ca}-\left[\mathrm{CO}_{3}^{2-}\right]$ correlation of Rathmann and Kuhnert [2008] 
and a $\left[\mathrm{CO}_{3}^{2-}\right]$ increase of $29 \mu \mathrm{mol} / \mathrm{kg}$ indicated by the coeval $\mathrm{Li} / \mathrm{Ca}$ increase. This small change in $\mathrm{Sr} / \mathrm{Ca}$ may reflect a coeval increase in seawater $\mathrm{Sr} / \mathrm{Ca}$. As sea level fell across the EOT, an increase in $\mathrm{Sr} / \mathrm{Ca}$ may be expected due to erosion of high-Sr/Ca shelf carbonates [Stoll and Schrag, 1998], however, an accelerated increase in seawater $\mathrm{Sr} / \mathrm{Ca}$ has not yet been observed across the EOT [Billups et al., 2004].

[20] Although we cannot unambiguously resolve the issue of absolute changes in ambient deep water $\left[\mathrm{CO}_{3}^{2-}\right]$ at Site 1263 across the EOT, any change in deep water carbonate chemistry would impact benthic $\mathrm{Mg} / \mathrm{Ca}$ ratios. An increase in deep water $\left[\mathrm{CO}_{3}^{2-}\right]$ would elevate $\mathrm{Mg} / \mathrm{Ca}$ in benthic foraminiferal shells [Elderfield et al., 2006; Yu and Elderfield, 2008]. Had we ascribed the observed increase in benthic $\mathrm{Mg} / \mathrm{Ca}$ across the EOT entirely to temperature changes and applied the calibration for Cibicidoides from Lear et al. [2002], the resulting temperature change of approximately $1^{\circ} \mathrm{C}$ would be within the range of calibration error and therefore insignificant. Conversely, a $29 \mu \mathrm{mol} / \mathrm{kg}$ increase in $\left[\mathrm{CO}_{3}^{2-}\right]$ as indicated by $\mathrm{Li} / \mathrm{Ca}$ would result in a $\mathrm{Mg} / \mathrm{Ca}$ increase of about $0.25 \mathrm{mmol} / \mathrm{mol}$, similar to the observed change in our record (Figure $3 \mathrm{c}$ ). Therefore, even at this relatively shallow site, the increase in $\left[\mathrm{CO}_{3}^{2-}\right]$ that is associated with a deepening of CCD and increase in benthic foraminiferal $\mathrm{Li} / \mathrm{Ca}$ could readily account for the rising $\mathrm{Mg} / \mathrm{Ca}$ and simulate an apparent warming during the EOT.

\section{Conclusions}

[21] Although positioned $\sim 1 \mathrm{~km}$ above the lysocline in the latest Eocene, benthic foraminiferal $\mathrm{Mg} / \mathrm{Ca}$ from Site 1263 appears to have recorded changes in $\left[\mathrm{CO}_{3}^{2-}\right]$ rather than temperature across the EOT. A $\mathrm{Li} / \mathrm{Ca}$ record from this intermediate water site suggests that $\left[\mathrm{CO}_{3}^{2-}\right]$ increased by $\sim 29 \mu \mathrm{mol} / \mathrm{kg}$ across the EOT. Together with the close coupling of the benthic $\mathrm{Mg} / \mathrm{Ca}$ and $\% \mathrm{CaCO}_{3}$ records across the benthic $\delta^{18} \mathrm{O}$ increase, we consider the $\mathrm{Li} / \mathrm{Ca}$ evidence to indicate that $\mathrm{Mg} / \mathrm{Ca}$ was predominantly controlled by $\Delta\left[\mathrm{CO}_{3}^{2-}\right]$, rather than temperature, across the EOT, as has previously been observed at deep sites. In the latest Eocene, $\mathrm{Mg} / \mathrm{Ca}$ may have been more sensitive to temperature based on the stronger correlation of $\mathrm{Mg} / \mathrm{Ca}$ with benthic $\delta^{18} \mathrm{O}$ and its anticorrelation with $\% \mathrm{CaCO}_{3}$ or with $\mathrm{Li} / \mathrm{Ca}$. We propose that the $\mathrm{Mg} / \mathrm{Ca}$ sensitivity of $O$. umbonatus switched from a temperature influence to $a\left[\mathrm{CO}_{3}^{2-}\right]$ control at the onset of the benthic $\delta^{18} \mathrm{O}$ increase due to a significant increase in intermediate water $\left[\mathrm{CO}_{3}^{2-}\right]$. Without a correction method, the sensitivity of benthic $\mathrm{Mg} / \mathrm{Ca}$ to $\left[\mathrm{CO}_{3}^{2-}\right]$ prevents this proxy from quantifying deep or intermediate water cooling across the EOT. Coupled $\delta^{18} \mathrm{O}$ and $\mathrm{Mg} / \mathrm{Ca}$ for thermoclinedwelling $S$. utilizindex suggest no change in thermocline temperature and therefore a $0.6 \%$ increase in $\delta \mathrm{w}$ at the EOT, similar to Lear et al. [2008], negating the necessity for extensive bipolar glaciation [Coxall et al., 2005]. Deep or intermediate water cooling of at least $2^{\circ} \mathrm{C}$ would account for the remainder of the benthic $\delta^{18} \mathrm{O}$ increase.

[22] A dissolution event, identified by an interval of low $\% \mathrm{CaCO}_{3}$ and $\mathrm{Li} / \mathrm{Ca}$ ratio, is observed at the onset of the benthic $\delta^{18} \mathrm{O}$ increase and is also recognized in a number of other sites. Further investigation of this time interval is essential to understanding what caused the apparent transient shoaling of the CCD and what influence it may have had on the dramatic changes in global climate that followed.

[23] Acknowledgments. We thank IODP for granting access to samples from ODP Site 1263. V.L.P. acknowledges Hilary Blagbrough for technical support, Mike Hall, James Rolf, and Mervyn Greeves for analytical support, and Linda Booth for assistance with foraminiferal identification. Alastair Graham is thanked for assistance in preparing Figure 1. S.K. publishes with the permission of the Executive Director of the British Geological Survey (NERC). Helen Coxall and Stephen Schellenberg are thanked for insightful reviews which have significantly improved this manuscript. We thank Rainer Zahn for the editorial handling and numerous suggestions as to how to improve the manuscript.

\section{References}

Anand, P., H. Elderfield, and M. H. Conte (2003), Calibration of $\mathrm{Mg} / \mathrm{Ca}$ thermometry in planktonic foraminifera from a sediment trap time series, Paleoceanography, 18(2), 1050, doi:10.1029/2002PA000846.

Barker, S. M., M. Greaves, and H. Elderfield (2003), A study of cleaning procedures used for foraminiferal $\mathrm{Mg} / \mathrm{Ca}$ paleothermometry, Geochem. Geophys. Geosyst., 4(9), 8407, doi:10.1029/2003GC000559.

Berggren, W. A., D. V. Kent, C. C. Swisher III, and M.-P. Aubry (1995), A revised Cenozoic geochronology and chronostratigraphy, in Geochronology, Time Scales and Global Stratigraphic Correlation, edited by W. A. Berggren et al., Spec. Publ. SEPM Soc. Sediment. Geol., 54, 129-212.

Billups, K., and D. P. Schrag (2003), Application of benthic foraminiferal $\mathrm{Mg} / \mathrm{Ca}$ ratios to questions of Cenozoic climate change, Earth Planet. Sci. Lett., 209, 181-195, doi:10.1016/ S0012-821X(03)00067-0.

Billups, K., R. E. M. Rickaby, and D. P. Schrag (2004), Cenozoic pelagic Sr/Ca records: Exploring a link to paleoproductivity, Paleoceanography, 19, PA3005, doi:10.1029/2004PA001011.
Bukry, D. (1973), Low-latitude coccolith biostratigraphic zonation, Initial Rep. Deep Sea Drill. Proj., 15, 685-703.

Bukry, D. (1975), Coccolith and silicoflagellate stratigraphy, northwestern Pacific Ocean, Deep Sea Drilling Project Leg 32, Initial Rep. Deep Sea Drill. Proj., 32, 677-701.

Cande, S. C., and D. V. Kent (1995), Revised calibration of the geomagnetic polarity timescale for the Late Cretaceous and Cenozoic, J. Geophys. Res., 100, 6093-6095, doi:10.1029/ 94JB03098.

Coxall, H. K., and P. N. Pearson (2007), The Eocene-Oligocene transition, in Deep-Time Perspectives on Climate Change: Marrying the Signal From Computer Models and Biological Proxies, edited by M. Williams et al., pp. 351-387, Geol. Soc., London.

Coxall, H. K., P. A. Wilson, H. Pälike, C. H. Lear, and J. Backman (2005), Rapid stepwise onset of Antarctic glaciation and deeper calcite compensation in the Pacific Ocean, Nature, 433, 53-57, doi:10.1038/nature03135.

DeConto, R., and D. Pollard (2003), Rapid Cenozoic glaciation of Antarctica induced by declining atmospheric $\mathrm{CO}_{2}$, Nature, 421, 245-249, doi:10.1038/nature01290.
Elderfield, H., J. Yu, P. Anand, T. Kiefer, and B. Nyland (2006), Calibrations for benthic foraminiferal $\mathrm{Mg} / \mathrm{Ca}$ paleothermometry and the carbonate ion hypothesis, Earth Planet Sci. Lett., 250, 633-649, doi:10.1016/j.epsl 2006.07.041.

Eldrett, J. S., I. C. Harding, P. A. Wilson, E. Butler, and A. P. Roberts (2007), Continental ice in Greenland during the Eocene-Oligocene, Nature, 446, 176-179, doi:10.1038/ nature 05591 .

Lear, C. H., and Y. Rosenthal (2006), Benthic foraminiferal $\mathrm{Li} / \mathrm{Ca}$ : Insights into Cenozoic seawater carbonate saturation state, Geology, 34(11), 985-988, doi:10.1130/G22792A.1.

Lear, C. H., H. Elderfield, and P. A. Wilson (2000), Cenozoic deep-sea temperatures and global ice volumes from $\mathrm{Mg} / \mathrm{Ca}$ in benthic foraminiferal calcite, Science, 287, 269-272, doi:10.1126/science.287.5451.269.

Lear, C. H., Y. Rosenthal, and N. Slowey (2002), Benthic foraminiferal $\mathrm{Mg} / \mathrm{Ca}$-paleo thermometry: A revised core-top calibration, Geochim. Cosmochim. Acta, 66, 3375-3387, doi:10.1016/S0016-7037(02)00941-9.

Lear, C. H., Y. Rosenthal, H. K. Coxall, and P. A. Wilson (2004), Late Eocene to early 
Miocene ice-sheet dynamics and the global carbon cycle, Paleoceanography, 19, PA4015, doi:10.1029/2004PA001039.

Lear, C. H., T. R. Bailey, P. N. Pearson, H. K. Coxall, and Y. Rosenthal (2008), Cooling and ice growth across the Eocene-Oligocene transition, Geology, 36, 251-254, doi:10.1130/ G24584A.1.

Lear, C. H., E. M. Mawbey, and Y. Rosenthal (2010), Cenozoic benthic foraminiferal $\mathrm{Mg} / \mathrm{Ca}$ and $\mathrm{Li} / \mathrm{Ca}$ records: Toward unlocking temperatures and saturation states, Paleoceanography, doi:10.1029/2009PA001880, in press.

Liu, Z., M. Pagani, D. Zinniker, R. DeConto, M. Huber, H. Brinkhuis, S. R. Shah, M. Leckie, and A. Pearson (2009), Global cooling during the Eocene-Oligocene climate transition, Science, 323, 1187-1190, doi:10.1126/ science. 1166368 .

Marriott, C. S., G. M. Henderson, R. Crompton, M. Staubwasser, and S. Shaw (2004), Effect of mineralogy, salinity and temperature on $\mathrm{Li} / \mathrm{Ca}$ and $\mathrm{Li}$-isotope composition of calcium carbonate, Chem. Geol., 212, 5-15, doi:10.1016/ j.chemgeo.2004.08.002.

Merico, A., T. Tyrell, and P. A. Wilson (2008), Eocene/Oligocene ocean de-acidification linked to Antarctic glaciation by sea-level fall, Nature, 452, 979-982, doi:10.1038/ nature 06853 .

Miller, K. G., J. V. Browning, M. P. Aubry, B. S. Wade, M. E. Katz, A. A. Kulpecz, and J. D. Wright (2008), Eocene-Oligocene global climate and sea-level changes: St. Stephens Quarry, Alabama, Geol. Soc. Am. Bull., 120, 34-53, doi:10.1130/B26105.1.

Müller, R. D., M. Sdrolias, C. Gaina, B. Steinberger, and C. Heine (2008), Longterm sea-level fluctuations driven by ocean basin dynamics, Science, 319, 1357-1362, doi:10.1126/science. 1151540 .

Okada, H., and D. Bukry (1980), Supplementary modification and introduction of code numbers to the low-latitude coccolith biostratigraphic zonation (Bukry, 1973; 1975), Mar. Micropaleontol., 5, 321-325, doi:10.1016/0377-8398 (80)90016-X
Pearson, P. N., P. W. Ditchfield, J. Singano, K. G. Harcourt-Brown, C. J. Nicholas, R. K Olsson, N. J. Shackleton, and M. A. Hall (2001), Warm tropical sea surface temperatures in the Late Cretaceous and Eocene epochs, Nature, 413, 481-487, doi:10.1038/35097000 Pearson, P. N., R. K. Olsson, C. Hemleben, B. T. Huber, and W. A. Berggren (2006), Atlas of Eocene Planktonic Foraminifera 513 pp., Allen, Lawrence, Kans.

Pekar, S. F., N. Christie-Blick, M. A. Kominz, and K. G. Miller (2002), Calibration between eustatic estimates from backstripping and oxygen isotopic records for the Oligocene Geology, 30, 903-906, doi:10.1130/0091-7613 (2002)030<0903:CBEEFB>2.0.CO;2.

Rathmann, S., and H. Kuhnert (2008), Carbonate ion effect on $\mathrm{Mg} / \mathrm{Ca}, \mathrm{Sr} / \mathrm{Ca}$ and stable isotopes on the benthic foraminifera Oridorsalis umbonatus off Namibia, Mar. Micropaleontol., 66, 120-133, doi:10.1016/j.marmicro.2007.08.001.

Riesselman, C. R., R. B. Dunbar, D. A. Mucciarone, and S. S. Kitasei (2007), High resolution stable isotope and carbonate variability during the early Oligocene climate transition: Walvis Ridge (ODP Site 1263), in Antarctica: A Keystone in a Changing World-Online Proceeding of the 10th ISAES, edited by A. K. Cooper and C. R. Raymond et al., U.S. Geol. Surv. Open File Rep., 2007-1047, Short Res. Pap. 095, 7 pp., doi:10.3133/of2007-1047.srp095.

Salamy, K. A., and J. C. Zachos (1999), Lates Eocene-early Oligocene climate change and Southern Ocean fertility: Inferences from sediment accumulation and stable isotope data, Palaeogeogr. Palaeoclimatol. Palaeoecol., 145, 61-77, doi:10.1016/S0031-0182 (98)00093-5

Sexton, P. F., P. A. Wilson, and P. N. Pearson (2006), Microstructural and geochemical perspectives on foraminiferal preservation: "Glassy" versus "frosty," Geochem. Geophys. Geosyst., 7, Q12P19, doi:10.1029/2006GC001291.

Stoll, H. M., and D. P. Schrag (1998), Effects of Quaternary sea level cycles on strontium in seawater, Geochim. Cosmochim. Acta, 62 ,
1107-1118, doi:10.1016/S0016-7037(98) 00042-8.

Van Andel, T. H. (1975), Mesozoic/Cenozoic calcite compensation depth and the global distribution of calcareous sediments, Earth Planet. Sci. Lett., 26, 187-194, doi:10.1016/ 0012-821X(75)90086-2.

$\mathrm{Yu}$, J. M., and H. Elderfield (2008), $\mathrm{Mg} / \mathrm{Ca}$ in the benthic foraminifera Cibicidoides wuellerstorfi and Cibicidoides mundulus Temperature versus carbonate ion saturation, Earth Planet. Sci. Lett., 276, 129-139, doi:10.1016/j.eps1.2008.09.015.

Yu, J. M., J. Day, M. Greaves, and H. Elderfield (2005), Determination of multiple element/ calcium ratios in foraminiferal calcite by quadrupole ICP-MS, Geochem. Geophys. Geosyst., 6, Q08P01, doi:10.1029/ 2005GC000964.

Yu, J. M., H. Elderfield, M. Greaves, and J. Day (2007), Preferential dissolution of benthic foraminiferal calcite during laboratory reductive cleaning, Geochem. Geophys. Geosyst., 8, Q06016, doi:10.1029/2006GC001571.

Zachos, J., M. Pagani, L. Sloan, E. Thomas, and K. Billups (2001), Trends, rhythms and aberrations in global climate $65 \mathrm{Ma}$ to present, Science, 292, 686-693, doi:10.1126/ science. 1059412

Zachos, J. C., et al. (2004), Proceedings of the Ocean Drilling Program, Initial Reports, vol. 208, Ocean Drill. Program, College Station, Tex.

S. Kender, British Geological Survey, Nottingham NG12 5GG, UK.

V. L. Peck, British Antarctic Survey, High Cross, Madingley Road, Cambridge CB3 0ET, UK. (vlp@bas.ac.uk)

C. R. Riesselman, Department of Geological and Environmental Sciences, Stanford University, Braun Hall, Bldg. 320, 450 Serra Mall, Stanford, CA 94305, USA.

J. Yu, Lamont-Doherty Earth Observatory of Columbia University, 61 Rte. 9W, Palisades, NY 10964, USA. 